\title{
ANALISIS PENERIMAAN RETRIBUSI PARKIR TEPI JALAN UMUM DI KOTA JAYAPURA
}

\author{
Stephanny Inagama Timisela ${ }^{1}$ \\ jurnalmkd@gmail.com \\ Meinarni Asnawi ${ }^{2}$ \\ meinarni.asnawi@gmail.com \\ Yundi Hafizrianda ${ }^{3}$ \\ hariman.andalan@gmail.com
}

\begin{abstract}
The purpose of this research was to acquire the information about magnitude of potential and level of leakage to income of parking retribution in road side in Jayapura municipality.

A sampling tehnique in this research was Slovin technique and data collection techniques were observation, interview and literature review. There were 2 data analysing approach employed such as quantitative and qualitative approach. The quantitative technique was to measure growth, contribution, elasticity, and calculation of potential and level of leakage. Meanwhile, the qualitative technique was for the description analysis based on research findings.

The findings of this research showed that: (a) management of parking retribution in road side in Jayapura municipality was not yet effective to optimise the potentialities of own source local revenue; (b) the research findings revealed that the perking retribution for Road Side in Jayapura municipality was IDR 914.928.000,- per year with 59.13 per cent level of leakage or equal to IDR 373.968.000,- per year; (c) there were some strategies to anticipate the issue of leakage in realisation and potential optimisation of road side parking in Jayapura municipality such as improvement and managing regulation, human resource, the society awareness, institutional system and procedures.
\end{abstract}

Keywords: Own Source Local Revenue, Retribution of Road Side parking, Leakage

\section{PENDAHULUAN}

Kota Jayapura merupakan pusat lbu Kota Pemerintahan di Provinsi Papua, selain itu daerah ini merupakan barometer pembangunan yang mana terlihat bahwa kondisi pencapaian makro yang cukup membanggakan di Kota Jayapura. Kondisi Pembangunan manusia merupakan tertinggi di Kota Jayapura yakni ditandai dengan pertumbuhan yang posif dengan 71,88 persen tahun 2004 mampu didorong hingga pada tahun 2013 mencapai 77,12 persen. Hal ini mendandakan bahwa Kota Jayapura mampu menciptakan kualitas pendidikan, kesehatan, dan ekonomi masyarakat yang berdomisili di Kota Jayapura.

Sesuai dengan Undang-Undang Nomor 17 Tahun 2003 tentang Keuangan Negara ,UU Nomor 32 Tahun 2004 tentang Pemerintahan Daerah dan UU Nomor 33 Tahun 2004 tentang Perimbangan Keuangan antara Pemerintah Pusat dan

\footnotetext{
${ }_{1}^{1}$ Alumni Mahasuswa Magister Keuangan Daerah Universitas Cenderawasih

${ }^{2}$ Staf Dosen Jurusan Akuntansi Fakultas Ekonomi \& Bisnis Universitas Cenderawasih

${ }^{3}$ Staf Dosen Jurusan IImu Ekonomi Fakultas Ekonomi \& Bisnis Universitas Cenderawasih
} 
Pemerintah Daerah, dan Peratuan Pemerintah Nomor 58 Tahun 2005 tentang Pengelolaan Keuangan Daerah, yang ditindaklanjuti Peraturan Dalam Negeri Peraturan Dalam Negeri No 59 tahun 2007 perubahan ke dua dari Permendagri Nomor 13 Tahun 2006 tentang Pedoman Pengelolaan Keuangan Daerah, APBD merupakan dasar pengelolaan keuangan daerah dalam masa 1 (satu) tahun anggaran terdiri atas pendapatan daerah, belanja daerah, dan pembiayaan daerah.

Peraturan Daerah Nomor 14 Tahun 2014, menyatakan bahwa dengan Retribusi Pelayanan Parkir di Tepi Jalan Umum dipungut Retribusi sebagai Pembayaran atas pelayanan penyediaan Tempat Parkir di Tepi Jalan Umum. Dalam pelaskanaan penarikan Retribusi parkir, sebagai salah satu langkah yang dilakukan untuk dapat meningkatkan penerimaan Pendapatan Asli Daerah Kota Jayapura sendiri menghadapi persoalan yakni, yaitu keterbatasan lahan parkir kendaraan. Persoalan ini terletak manajemen ruang parkir yang belum baik sehingga memberikan dampak kepada parkir liar di tepian jalan umum. Dengan pengaturan tataruang parkir yang baik maka mampu berpotensi sebagai objek pendapatan daerah. Bertumbuhnya jumlah kendaraan di Kota Jayapura tidak sebanding dengan fasilitas jalan raya dan ketersediaan lahan parkir bagi pengendara kendaraan roda dua (motor), dan kendaraan roda empat (mini bus, sedan, pick-up).

Fenomena yang terjadi di Kota Jayapura terkait pemungutan retribusi parkir di tepi jalan umum adalah, maraknya petugas parkir illegal (liar) dan juga petugas parkir legal yang menarik retribusi parkir tanpa menyerahkan karcis parkir. Tetapi jika dikaji masyarakat yang menggunakan fasilitas parkir tepi jalan tidak segan untuk membayar retribusi tersebut asalkan petugas parkir tersebut menjalankan tugas sebagaimana mestinya (menyerahkan karcis parkir dan bukan juru parkir illegal).

Menurut Undang-Undang Nomor 32 Tahun 2004 tentang Pemerintahan Daerah, yang dimaksud dengan Pendapatan Daerah adalah semua hak daerah yang diakui sebagai penambah nilai kekayaan bersih dalam periode tahun anggaran yang bersangkutan.

Dan menurut Undang-Undang Nomor 33 Tahun 2004 tentang Penimbangan Keuangan antara Pemerintah Pusat dan Pemerintah Daerah, yang dimaksud dengan Pendapatan Daerah adalah semua hak Pemerintah Daerah yang diakui sebagai penambah nilai kekayaan bersih dalam periode tahun bersangkutan.

Adapun yang dimaksud dengan pengertian pendapatan daerah sebagaimana yang dikemukakan oleh Dinas Pendapatan Daerah Kota Jayapura 
bahwa Pendapatan Daerah adalah sumber penerimaan ataupun barang yang dapat dinilai dengan uang yang menjadi hak atau milik daerah berdasarkan peraturan perundang-undangan yang berlaku dan penerimaan pendapatan tersebut harus disetor ke kas daerah dan selanjutnya dikelola untuk membiayai pengeluaran dalam rangka penyelenggaraan urusan rumah tangga daerah. Adapun sumber-sumber pendapatan daerah menurut Undang-Undang Nomor 32 Tahun 2004 adalah sebagai berikut :

1. Pendapatan Asli Daerah yang terdiri dari :

a. Hasil Pajak Daerah ;

b. Hasil Retribusi Daerah ;

1. Retribusi Jasa Umum

Sumber-sumbernya adalah:

1) Retribusi Pelayanan Kesehatan

2) Retribusi Pelayanan Persampahan/Kebersihan

3) Retribusi Penggantian atau Biaya Cetak KTP dan Akta Catatan Sipil

4) Retribusi Pelayanan Pemakaman dan Pengabuan Mayat

5) Retribusi Parkir di tepi Jalan Umum

6) Retribusi Pelayanan Pasar

7) Retribusi tempat Khusus Parkir

8) Retribusi Pemerikasaan alat pemadam Kebakaran

9) Retribusi Tata Cara Pemasukan Minuman Beralkohol

10) Retribusi Pedagang Kaki Lima

11) Retribusi Jasa Ketatausahaan

2. Retribusi Jasa Usaha Sumber-sumbernya berasal dari :

1) Retribusi Rumah Potong Hewan

2) Retribusi Pemakaian Kekayaan Daerah

3) Retribusi Terminal

4) Retribusi Tempat Rekreasi dan Olahraga

5) Retribusi Benih Ikan

3. Retribusi Perijinan Tertentu Sumber-sumbernya berasal dari :

1) Retribusi ljin Mendirikan Bangunan

2) Retribusi Tempat Penjualan Minuman Beralkohol

3) Retribusi ljin Gangguan

4) Retribusi ljin Trayek

5) Retribusi ljin Usaha Pariwisata 
6) Retribusi ljin Praktek Pelayanan Kesehatan dan Farmasi

7) Retribusi ljin Usaha Industri dan Perdagangan

8) Retribusi ljin Usaha Jasa Pos dan Telekomunikasi

9) Retribusi ljin Usaha Perikanan

10) Retribusi ljin Usaha Jasa Konstruksi

c. Hasil Pengelolaan Kekayaan Daerah Yang Dipisahkan

1. Penerimaan Lain-Lain PAD yang sah.

Penerimaan lain-lain PAD yang sah, yaitu :

1) Hasil Penjualan Kekayaan Daerah Yang Tidak Dipisahkan;

2) Jasa Giro

3) Pendapatan Bunga;

4) Keuntungan Selisih Nilai Tukar Rupiah Terhadap Mata Uang Asing;

5) Komisi, Potongan Ataupun Bentuk Lain Sebagai Akibat Dari Penjualan Dan Atau Pengadaan Barang Dan Atau Jasa Oleh Daerah;

6) Hasil Penjualan Milik Daerah;

7) Sumbangan Pihak Ketiga/Sisa Uudp;

8) Penerimaan Ganti Rugi Atas Kekayaan Daerah;

9) Setoran Kelebihan Pembayaran Kepada Pihak Ketiga;

10) Denda Kelembatan Pelaksanaan Pekerjaan Daerah;

11) Angsuran Cicilan Kendaraan Bermotor;

12) Angsuran Cicilan Rumah Dinas;

13) Sewa Kapal Tobi;

14) Hasil Penjualan Bibit Ternak;

15) Tunggakan Pajak/Retribusi Daerah;

16) Perikanan

17) Pariwisata

18) ST, UK, DPU.

2. Dana Pertimbangan

Dana perimbangan dibagi menurut jenis pendapatan :

1) Dana Bagi Hasil, Jenis Data Bagi Hasil dirinci menurut objek pendapatan yang mencakup:

a) Bagi Hasil Pajak,

b) Bagi Hasil Bukan Pajak,

2) Dana Alokasi Umum;

3) Dana Alokasi Khusus. 


\section{Pendapatan Asli Daerah}

Menurut Mardiasmo (2002), Pendapatan Asli Daerah adalah penerimaan yang diperoleh dari sektor pajak daerah, retribusi daerah, hasil perusahaan milik daerah, hasil pengelolaan kekayaan daerah yang dipisahkan, dan lain-lain pendapatan asli daerah yang sah.

Menurut Undang-Undang Nomor 33 Tahun 2004 tentang Perimbangan Keuangan antara Pemerintah Pusat dan Pemerintah Daerah, yang dimaksud dengan Pendapatan Asli Daerah adalah pendapatan yang diperoleh daerah yang dipungut berdasarkan Peraturan Daerah sesuai dengan peraturan perundangundangan. Pendapatan Asli Daerah ini mewujudkan kemampuan suatu daerah dalam menghimpun suatu dana serta memanfaatkan keunggulan-keunggulan sumber keuangan daerahnya sehingga dapat mendukung pembiayaan dan penyelenggaraan pemerintahan serta pembiayaan pembangunan daerah sesuai dengan konsekuensi dan kedudukannya sebagai daerah otonom sehingga mengarah pada perwujudan desentralisasi.

\section{Pelayanan Publik}

Istilah publik berasal dari bahasa Inggris public yang berarti umum, masyarakat, negara. Kata publik sebenarnya sudah diterima menjadi Bahasa Indonesia Baku menjadi Publik yang berarti umum, orang banyak, ramai. Padanan kata yang tepat digunakan adalah praja yang sebenarnya bermakna rakyat sehingga lahir istilah pamong praja yang berarti pemerintah yang melayani kepentingan seluruh rakyat.

Secara operasional, pelayanan publik yang diberikan kepada masyarakat dapat dibedakan dalam dua kelompok besar yaitu; pertama, pelayanan publik yang diberikan tanpa memperhatikan orang perseorangan, tetapi keperluan masyarakat secara umum yang meliputi penyediaan sarana dan prasarana transportasi, penyediaan pusat-pusat kesehatan, pembangunan lembaga-lembaga pendidikan, pemeliharaan keamanan, dan lain sebagainya; kedua, pelayanan yang diberikan secara orang perseorangan yang meliputi kartu penduduk dan surat-surat lainnya

Menurut pasal 1 UU No. 25 Tahun 2009 tentang Pelayanan Publik mendefiniskan pelayanan publik adalah kegiatan atau rangkaian kegiatan dalam rangka pemenuhan kebutuhan pelayanan sesuai dengan peraturan perundangundangan bagi setiap warga negara dan penduduk atas barang, jasa, dan/atau pelayanan administratif yang disediakan oleh penyelenggara pelayanan publik. 


\section{Pengertian Retribusi Daerah}

Retribusi daerah sebagaimana halnya pajak daerah merupakan salah satu pendapatan asli daerah yang diharapkan menjadi salah satu sumber pembiayaan penyelenggaraan pemerintahan dan pembangunan daerah, untuk meningkatkan dan memeratakan kesejahteraan masyarakat (Rohmat Soemitro, 2004)

Menurut (Rohmat Soemitro, 2004) mengatakan bahwa retribusi daerah adalah pembayaran kepada negara yang dilakukan kepada mereka yang menggunakan jasa-jasa negara, artinya retribusi daerah sebagai pembayaran atas jasa atau karena mendapat pekerjaan usaha atau milik daerah bagi yang berkepentingan atau jasa yang diberikan oleh daerah baik secara langsung maupun tidak langsung. Oleh karena itu, setiap pungutan yang dilakukan oleh pemerintah daerah senantiasa berdasarkan prestasi dan jasa yang diberikan kepada masyarakat sehingga keleluasaan retribusi daerah terletak pada yang dinikmati oleh masyarakat. Jadi, retribusi sangat berhubungan erat dengan jasa layanan yang diberikan pemerintah daerah kepada yang membutuhkan.

Munawir (1990 : 45), menyebutkan definisi retribusi adalah sebagai berikut. "Retribusi adalah iuran kepada pemerintah yang dapat dipaksakan dan jasabalik secara langsung dapat ditunjuk, paksaan ini bersifat ekonomis karena siapa saja yang tidak merasakan jasa balik dari pemerintah ia tidak akan dikenakan iuran tersebut".

Sedangkan menurut Undang-undang No. 28 Tahun 2009 yang dimaksud dengan retribusi daerah, yang selanjutnya disebut Retribusi, adalah pungutan Daerah sebagai pembayaran atas jasa atau pemberian izin tertentu yang khusus disediakan dan/atau diberikan oleh Pemerintah Daerah untuk kepentingan orang pribadi atau Badan.

Menurut Pasal 2 ayat (26) Undang-undang No. 34 tahun 2000 Perubahan atas Undang-undang No. 18 tahun 1997 tentang pajak daerah dan retribusi daerah menyebutkan definisi retribusi daerah adalah sebagai berikut "Retribusi Daerah yang selanjutnya disebut Retribusi, adalah Pungutan Daerah sebagai pembayaran atas jasa atau pemberian izin tertentu yang khusus disediakan dan atau diberikan oleh Pemerintah Daerah untuk kepentingan orang pribadi atau badan".

\section{Retribusi Parkir}

Retribusi parkir merupakan salah satu bagian dari retribusi jasa umum, yakni retribusi atas jasa yang disediakan oleh pemerintah daerah untuk tujuan kepentingan umum serta dapat dinikmati oleh orang pribadi atau badan. Objek 
retribusi umum adalah pelayanan yang disediakan oleh pemerintah daerah untuk tujuan kepentingan dan kemanfaatan umum serta dapat dinikmati oleh orang pribadi atau badan. Tarif parkir merupakan retribusi atas penggunaan lahan parkir dipinggir jalan yang besarannya ditetapkan oleh Pemerintah Kabupaten/ Kota berdasarkan UU tentang Pajak Daerah dan Retribusi Daerah yang selanjutnya ditetapkan di tingkat Kabupaten/Kota dengan Peraturan Daerah. Untuk mengoptimalkan pendapatan dari tarif parkir adalah dengan mengawasi proses dari pada retribusi parkir itu apakah sudah berjalan sesuai Peraturan Daerah yang berlaku.Penetapan tarif parkir merupakan salah satu perangkat yang digunakan sebagai alat dalam kebijakan manajemen lalu lintas di suatu kawasan/kota untuk membatasi penggunaan kendaraan pribadi menuju ke suatu kawasan tertentu yang perlu dikendalikan lalu lintasnya dan merupakan salah satu pendapatan asli daerah yang penting.

Prinsip dan sasaran tarif retribusi parkir bisa saja berbeda sesuai keputusan pemerintah daerah, misalnya dalam penetapan tarif retribusi parkir di tepi jalan umum yang rawan kemacetan dapat ditetapkan lebih tinggi dari pada di tepi jalan umum yang kurang rawan kemacetan dengan sasaran mengendalikan tingkat pengguna jasa parkir sehingga tidak menghalangi kelancaran lalu lintas. Dasar pengenaan retribusi parkir adalah jumlah pembayaran atau yang seharusnya dibayar untuk pemakaian tempat parkir. Dasar pengenaan pajak didasarkan pada klasifikasi tempat parkir, daya tampung dan frekwensi kendaraan bermotor, setiap kendaraan bermotor yang parkir ditempat parkir diluar badan jalan akan dikenakan tarif parkir yang ditetapkan oleh pengelola.

Tarif parkir ini merupakan pembayaran yang harus diserahkan oleh pengguna tempat parkir untuk pemakaian tempat parkir. Tarif parkir yang ditetapkan oleh pengelola tempat parkir diluar badan jalan yang memungut bayaran disesuaikan tarif parkir yang ditetapkan oleh pemerintah kabupaten.

\section{Retribusi Pelayanan Parkir Tepi Jalan Umum Di Kota Jayapura}

(Peraturan Daerah Nomor 14 Tahun 2007) Masyarakat Pengguna Tempat Parkir di Jalan Umum mengharapkan agar Pemerintah Daerah selalu meningkatkan pelayanan perparkiran, berupa penyediaan fasilitas tempat parkir dan peningkatan pelayanan kebersihan, kerapian, keamanan dan ketertiban di Tempat Parkir bagi Pengguna Tempat Parkir, sehingga fungsi tempat Parkir dan manfaatnya, dapat terwujud.

Atas penyediaan dan pelayanan tersubut di atas, dapat dipungut Retribusi Pelayanan Parkir di Tepi Jalan Umum yang jenis pungutannya 
digolongkan dalam Retribusi Jasa Umum, yaitu suatu pungutan dilakukan karena jasa yang disediakan atau diberikan oleh Pemerintah Daerah untuk kepentingan umum berupa penyediaan fasilitas dan pelayanan parkir di tepi jalan umum dan dapat dinikmati oleh orang pribadi atau badan usaha.

Dengan penetapan Peraturan Daerah tentang Retribusi Parkir Tepi Jalan Umum, maka peran masyarakat khususnya pengguna tempat parkir di tepi jalan umum telah secara langsung ikut berpartisipasi dalam pelaksanaan Pembangunan.

\section{METODE PENELITIAN}

\section{Lokasi Penelitian}

Penelitian ini dilaksanakan di Kota Jayapura Provinsi Papua, dimana yang menjadi lokasi Objek Penelitian yakni Lokasi Parkir Tepi Jalan Umum pada Distrik Abepura, Distrik Heram, Distrik Jayapura Selatan, dan Distrik Jayapura Utara.

\section{Jenis Dan Sumber Data}

Jenis dan sumber data yang digunakan untuk membahas penelitian ini adalah sebagai berikut:

\section{a. Jenis Penelitian}

Dalam penelitian ini, peneliti mengunakan pendekatan kuantitatif dan kualitatif. Pendekatan Kuantitatif digunakan dalam menganalisis penerimaan daerah Kota Jayapura yang bersumber dari Retribusi Parkir Pinggir Jalan Umum yang mana tipe penelitian ini merupakan timeseries, Sedangkan pendekatan kualitatif digunakan dalam menganalisis sifatnya deskriptif analitik terhadap Data yang diperoleh seperti hasil pengamatan, hasil pemotretan, analisis dokumen, catatan lapangan, disusun peneliti di lokasi penelitian, tidak dituangkan dalam bentuk angka-angka

\section{b. Sumber Data}

Data primer yaitu data yang dibuat oleh peneliti untuk maksud khusus menyelesaikan permasalahan yang sedang ditanganinya. Data dikumpulkan sendiri oleh peneliti langsung dari sumber pertama atau tempat objek penelitian. Pada penelitian ini diterapkan peneliti pada dokumentasi/pencatatan secara langsung pada 15 objek retribusi parkir pinggir jalan umum di Kota Jayapura.

Data sekunder yaitu data yang telah dikumpulkan untuk maksud selain menyelesaikan masalah yang sedang dihadapi. Data ini dapat ditemukan dengan cepat. Pada penelitian ini diterapkan peneliti pada dokumentasi 
penerimaan retribusi parkir pinggir jalan umum, Data Dalam Angka Kota Jayapura (DDA), Produk Domestik Regional Bruto (PDRB), Ringkasan APBD Kota Jayapura.

\section{Populasi Dan Sampel}

\section{1) Populasi}

Dalam kasus penelitian ini, maka objek penelitian yang di sebutkan sebagai populasi yakni seluruh area parkir tepi jalan umum di Kota Jayapura.

\section{a. Sampel}

Dalam kasus penelitian ini, maka objek penelitian yang di sebutkan sebagai sampel yakni sekelompok area parkir tepi jalan umum berdasarkan distrik di Kota Jayapura.

\section{b. Teknik Penentuan Sampel}

Terdapat 56 area parkir tepi jalan umum berdasarkan distrik di Kota Jayapura. Hal ini merupakan potensi kapasitas fiskal yang bersumber dari penerimaan Retribusi Daerah yang disumbangkan dari komponen Retribusi Parkir Pinggir Jalan Umum di Kota Jayapura. Dalam mementukan sampel, penulis menggunakan rumus Slovin sebagai alat untuk menghitung ukuran sampel Pada kasus dalam penelitian ini.

\section{$\mathbf{N}$}

$$
\text { Rumus Slovin } n=\frac{}{1+n \alpha-{ }^{2}}
$$

$$
\begin{aligned}
& \text { Keterangan: } \\
& n \quad=\text { Jumlah Sampel } \\
& \begin{array}{ll}
N & =\text { Jumlah Populasi } \\
\alpha & =\text { Margin Error }
\end{array}
\end{aligned}
$$

Melalui rumus Slovin, maka diperoleh jumlah sampel dalam penelitian ini yakni sebanyak 36 lokasi parkir tepi jalan umum di Wilayah Administrasi Kota Jayapura. Penelitian ini dilakukan pada 4 (empat) distrik, maka perumusan pengambilan sampel di masing-masing distrik menggunakan teknik Stratified Random Sampling dimana teknik ini mengambil sampel dengan memperhatikan strata (tingkatan) di dalam stratified data sebelumnya dikelompokkan tingkatan-tingkatan tertentu. 
Tabel 3.1

Jumlah Penentuan Sampel Stratified Random Sampling

\begin{tabular}{|c|c|c|c|c|c|c|}
\hline \multirow{2}{*}{ No } & \multirow{2}{*}{ Distrik } & \multicolumn{5}{|c|}{ Tingkatan stratified data } \\
\cline { 3 - 7 } & Abepura & AKB & AKTB & TAKS & TAKTS & Total \\
\hline 1 & 2 & 3 & 1 & 10 & 16 \\
\hline 2 & Heram & 0 & 0 & 0 & 3 & 3 \\
\hline 3 & Jayapura Selatan & 9 & 5 & 1 & 1 & 16 \\
\hline 4 & Jayapura Utara & 0 & 1 & 0 & 0 & 1 \\
\hline
\end{tabular}

Sumber : Data diolah, 2015

Berdasarkan tabel diatas, dengan demikian untuk wilayah distrik abepura terdapat sampel lokasi/juru parkir tepi jalan umum sebanyak 16, distrik heram sebanyak 3 lokasi, distrik jayapura selatan sebanyak 16 lokasi, dan Distrik Jayapura Utara sebanyak 1 lokasi. Dengan tingkatan terdapat sampel juru parkir 11 juru parkir AKB (Ada Karcis dan Berseragam), 9 juru parkir AKTB (Ada Karcis dan Tidak Berseragam), 2 juru parkir TAKS (Tidak Ada Karcis dan Seragam), dan TAKTS (Tidak Ada Karcis dan Tidak Berseragam).

\section{Teknik Pengumpulan Data}

Metoda pengumpulan data dilapangan yang mana akan dianalisis lebih lanjut. Oleh sebab itu diperlukan teknik pengumpulan data yang lazim digunakan dalam penelitian ilmiah, yakni Observasi, Wawancara dan Studi Kepustakaan.

\section{Metoda Analisis Data}

Untuk menjawab pertanyaaan dalam rumusan permasalahan pada bab sebelumnya, maka metoda analisis data sebagai berikut:

(a) Bagaimana penerimaan retribusi parkir tepi jalan umum di Kota Jayapura.

i. Growth Retribusi Parkir Pinggir Jalan Umum

$$
G x=\frac{X t-X(t-1)}{X(t-1)} \times 100 \%
$$

Keterangan:

Gx $\quad$ : Growth Retribusi Parkir

$X t \quad$ : Realisasi Penerimaan Retribusi Parkir Tahun Tertentu

$X(t-1) \quad:$ Realisasi Penerimaan Retribusi Parkir Tahun Sebelumnya

ii. Share Retribusi Parkir Pinggir Jalan Umum terhadap Penerimaan PAD

$$
P n=\frac{Q X n}{Q Y n} \times 100 \%
$$


Keterangan:

Pn : Share penerimaan retribusi daerah terhadap $P A D$

$X y \quad:$ Realisasi PAD

$X X \quad$ : Realisasi Retribusi Parkir

$n \quad:$ Tahun (periode tertentu)

iii. Elastisitas Retribusi Parkir Pinggir Jalan Umum terhadap Penerimaan PAD

$$
\text { Elastisitas }=\frac{\% \text { Pertumb.retribusi parkir tepi jalan umum }}{\% \text { Pertumbuhan PAD }}
$$

\section{(b) Kebocoran Retribusi Parkir Tepi Jalan Umum}

Dalam penelitian ini terdapat 3 tipe perilaku yang dilakukan oleh juru parkir maupun pelanggan parkir, antara lain: (1) Tidak Terima Karcis, (2) Terima Karcis, (3) Tidak Membayar Karcis. Pengukuran nilai kebocoran retribusi parkir dilakukan melalui beberapa tahapan sebagai berikut:

i. $\quad$ Potensi Aktual : TDK + TK + TMK

Keterangan:

TDK = Tidak Menerima Karcis

$\mathrm{TK}=$ Terima Karcis

TMK = Tidak Membayar Karcis

ii. Kebocoran Retr. Parkir = Potensi Aktual - Terima Karcis x 365 hari

iii. Tingkat Kebocoran $=\frac{\text { Kebocoran Retribusi Parkir }}{\text { Potensi Retribusi Parkir }} \times 100$

Nilai potensi aktual diatas meruapakn nilai aktual /hari sehingga untuk mendapatkan nilai aktual /bulan ataupun /tahun, maka perlu dilakukan konversi terhadap satuan bulanan maupun tahunan.

\section{HASIL DAN PEMBAHASAN}

\section{Penerimaan Retribusi Parkir Tepi Jalan Umum Di Kota Jayapura}

Dalam analisis pada pembahasan ini, terdapat tiga analisis pokok yang digunakan untuk merekam fenomena yang terjadi mengenai pengelolaan retribusi jasa umum khususnya penerimaan retribusi tepi jalan umum di Kota Jayapura secara timeseries. Adapun pendekatan kuantitatif yang diterapakan antara lain analisis pertumbuhan, kontribusi, dan elastisitas. 


\section{Tabel Perkembangan Realisasi Parkir Tepi Jalan Umum di Kota Jayapura Tahun 2005-2015}

\begin{tabular}{|c|r|r|r|}
\hline \multirow{2}{*}{ Tahun } & \multirow{2}{*}{$\begin{array}{c}\text { Realisasi Parkir Tepi } \\
\text { Jalan Umum (Rp) }\end{array}$} & \multicolumn{2}{|c|}{ Pertumbuhan } \\
\cline { 3 - 4 } & Realisasi Parkir Tepi Jalan Umum \\
\hline 2005 & $205,214,000$ & \multicolumn{1}{|c|}{ Rp } & \multicolumn{1}{c|}{ - } \\
\hline 2006 & $265,154,100$ & $59,940,100$ & $29 \%$ \\
\hline 2007 & $737,575,475$ & $472,421,375$ & $178 \%$ \\
\hline 2008 & $886,060,200$ & $148,484,725$ & $20 \%$ \\
\hline 2009 & $939,647,200$ & $53,587,000$ & $6 \%$ \\
\hline 2010 & $930,646,050$ & $(9,001,150)$ & $-1 \%$ \\
\hline 2011 & $662,960,000$ & $(267,686,050)$ & $-29 \%$ \\
\hline 2012 & $567,730,550$ & $(95,229,450)$ & $-14 \%$ \\
\hline 2013 & $1,132,758,300$ & $565,027,750$ & $100 \%$ \\
\hline 2014 & $1,050,358,250$ & $(82,400,050)$ & $-7 \%$ \\
\hline 2015 & $1,132,758,301$ & $82,400,051$ & $8 \%$ \\
\hline
\end{tabular}

Sumber: Dispenda Kota Jayapura, 2016 (Data diolah)

Secara keseluruhan realisasi penerimaan retribusi parkir tepi jalan umum di Kota Jayapura mengalami kondisi yang kurang efektif, dimana berdasarkan informasi kualitatif dari berbagai sumber menunjukkan bahwa kondisi realisasi penerimaan parkir tepi jalan umum di Kota Jayapura masih jauh dari nilai penetapan target tahunan. Kondisi tidak optimal dalam pengelolaan potensi daerah ialah terlihat dari rata-rata selama 11 tahun (2005-2015) hanya sebesar Rp.773 Juta.

\section{Gambar Perkembangan Realisasi Parkir Tepi Jalan Umum di Kota Jayapura Tahun 2005-2015}

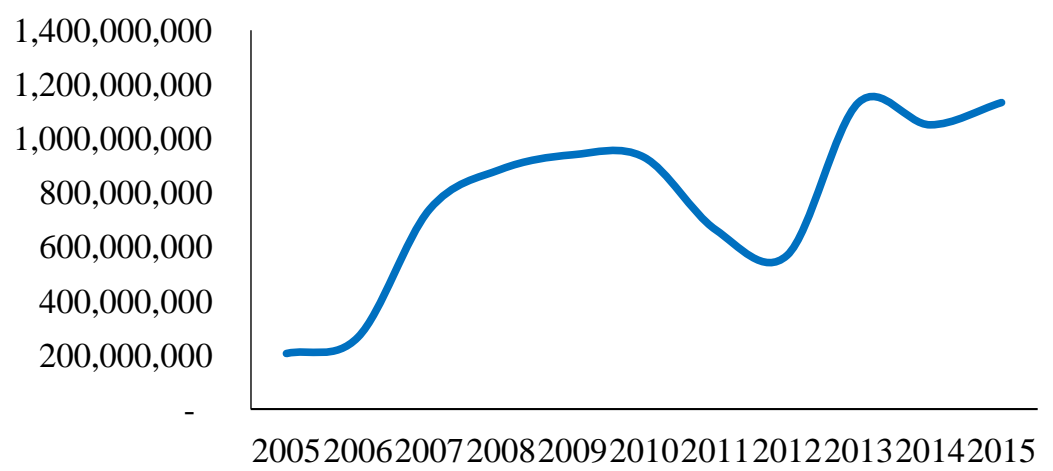

Sumber: Dispenda Kota Jayapura, 2016 (Data diolah)

Secara spesifik terlihat, perkembangan realisasi parkir secara umum mengalami kondisi positif, dimana menandakan cukup stabil dalam pertumbuhan realisasi penerimaan. Terkecuali, pada tahun 2012, dan tahun 2014 mengalami 
penurunan angka realisasi penerimaan parkir tepi jalan umum di Kota Jayapura. Pertumbuhan terbesar dicapai pada tahun 2007 dan 2013 dimana berdasarkan tabel 4.5 menunjukkan angka prosentase sama ataupun diatas 100 persen. Pada tahun 2013 Pemerintah Kota Jayapura, mampu merealisasikan nilai retribusi jasa parkir tepi jalan umum menempati angka Rp.1 Milyar hal ini bertahan hingga pada tahun 2015 dimana realisasi penerimaan sebesar Rp.1,132,758,301,--

\section{Tabel Share Realisasi Parkir Tepi Jalan Umum terhadap Retribusi Daerah dan Pendapatan Asli Daerah di Kota Jayapura Tahun 2005-2015}

\begin{tabular}{|c|c|c|c|}
\hline \multirow[b]{2}{*}{ Tahun } & \multirow[b]{2}{*}{$\begin{array}{l}\text { Realisasi Parkir Tepi } \\
\text { Jalan Umum (Rp) }\end{array}$} & \multicolumn{2}{|c|}{ Share } \\
\hline & & $\begin{array}{c}\text { Terhadap } \\
\text { PAD (\%) }\end{array}$ & $\begin{array}{c}\text { Terhadap } \\
\text { Retribusi (\%) }\end{array}$ \\
\hline 2005 & $205,214,000$ & $1 \%$ & $2 \%$ \\
\hline 2006 & $265,154,100$ & $1 \%$ & $2 \%$ \\
\hline 2007 & $737,575,475$ & $2 \%$ & $6 \%$ \\
\hline 2008 & $886,060,200$ & $2 \%$ & $6 \%$ \\
\hline 2009 & $939,647,200$ & $2 \%$ & $5 \%$ \\
\hline 2010 & $930,646,050$ & $2 \%$ & $4 \%$ \\
\hline 2011 & $662,960,000$ & $1 \%$ & $3 \%$ \\
\hline 2012 & $567,730,550$ & $1 \%$ & $3 \%$ \\
\hline 2013 & $1,132,758,300$ & $1 \%$ & $4 \%$ \\
\hline 2014 & $1,050,358,250$ & $1 \%$ & $7 \%$ \\
\hline 2015 & $1,132,758,301$ & $1 \%$ & $4 \%$ \\
\hline
\end{tabular}

Sumber: Dispenda Kota Jayapura, 2016 (Data diolah)

Share realisasi penerimaan retribusi parkir tepi jalan umum di Kota Jayapura, menunjukkan kemampuan objek retribusi jasa umum ini berkontribusi terhadap Pendapatan Asli Daerah dan Retribusi Daerah. Kurun waktu 2005-2015 rata-rata realisasi Pendapatan Asli Daerah (PAD) sebesar Rp.64 Milyar, sedangkan untuk realisasi Retribusi Daerah rata-rata mampu merealisasikan sebesar Rp. 18 Milyar.

\section{Gambar Perkembangan Realisasi PAD dan Retribusi Daerah di Kota Jayapura Tahun 2005-2015}

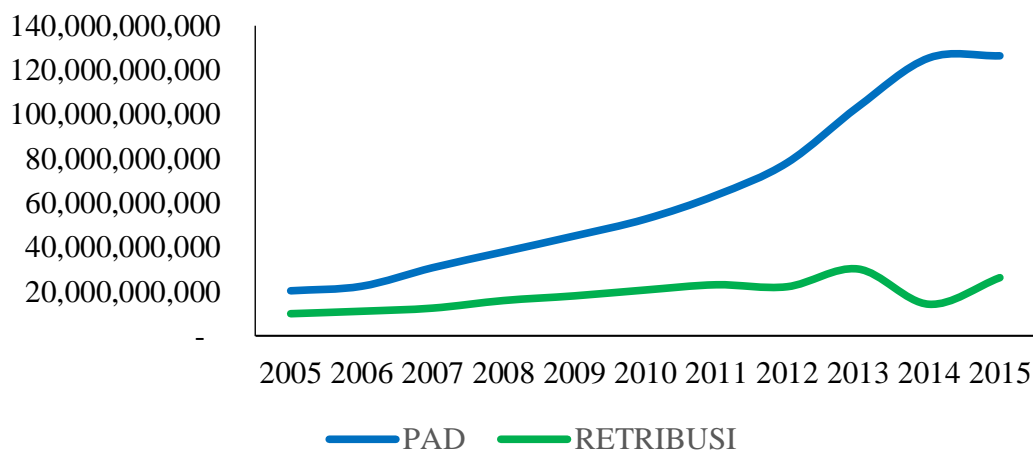


Sumber: Dispenda Kota Jayapura, 2016 (Data diolah)

Fenomena retribusi terlihat realisasi Retribusi Daerah sepanjang tahun 20052015 penerimaan masih berada pada nilai 20-40 Milyar, sedangkan untuk Pendapatan Asli Daerah (PAD) pada tahun 2012 menunjukkan lonjakan yang cukup signifikan, dimana pada tahun 2015 Pemerintah Daerah Kota Jayapura mampu merealisasikan seluruh komponen PAD sebesar Rp.126 Milyar. Informasi lainnya melalui tabel 4.6 diatas yakni kontribusi yang masih cukup kecil terhadap Pendapatan Asli Daerah hanya sebesar 1 persen sampai dengan 2 persen, sedangkan untuk Retribusi Daerah kontribusi parkir tepi jalan umum sebesar 2 persen sampai dengan 7 persen. Berdasarkan klasifikasi penilaian kontribusi penerimaan retribusi parkir tepi jalan umum terhadap PAD dan Retribusi di Kota Jayapura sepanjang tahun 2005-2015 tergolong prosentase kontribusi $\leq 10$, hal ini menandakan bahwa pengelolaan retribusi parkir tepi jalan umum "sangat kurang" terkait optimalisasi penerimaan objek retribusi parkir di tepi jalan umum di Kota Jayapura.

\section{Tabel Elastisitas Parkir Tepi Jalan Umum di Kota Jayapura Tahun 2006-2015}

\begin{tabular}{|c|c|c|c|c|}
\hline Tahun & $\begin{array}{c}\text { Pendapatan } \\
\text { Asli Daerah }\end{array}$ & $\begin{array}{c}\text { Parkir Tepi } \\
\text { Jalan Umum }\end{array}$ & $\begin{array}{c}\text { Koefisien } \\
\text { Elastisitas }\end{array}$ & $\begin{array}{c}\text { Sifat } \\
\text { Elastisitas }\end{array}$ \\
\hline 2006 & 0.10 & 0.29 & 2.89 & Elastis \\
\hline 2007 & 0.37 & 1.78 & 4.77 & Elastis \\
\hline 2008 & 0.23 & 0.20 & 0.86 & Unitary \\
\hline 2009 & 0.19 & 0.06 & 0.32 & Inelastis \\
\hline 2010 & 0.17 & -0.01 & -0.06 & Inelastis \\
\hline 2011 & 0.20 & -0.29 & -1.40 & Elastis \\
\hline 2012 & 0.23 & -0.14 & -0.62 & Unitary \\
\hline 2013 & 0.32 & 1.00 & 3.07 & Elastis \\
\hline 2014 & 0.21 & -0.07 & -0.34 & Inelastis \\
\hline 2015 & 0.01 & 0.08 & 10.17 & Elastis \\
\hline
\end{tabular}

Sumber: Data diolah, Tahun 2016

Mencermati tabel mengenai perhitungan elastisitas retribusi parkir tepi jalan umum, dimana situasi perkembangan pertumbuhan Pendapatan Asli Daerah (PAD) cenderung berkembang secara positif, kondisi berbeda terjadi pada pertumbuhan realisasi penerimaan parkir tepi jalan umum yakni terjadi pertumbuhan negatif. Yang mana memberikan pengertian bahwa pada tahun tertentu seperti terjadi sepanjang tahun 2010-2012 dan terulang kembali pada tahun 2012 sebesar -0.62 poin. Gambaran tahunan mengenai elastisitas, 
menunjukkan bahwa pada tahun 2006-2007 dengan koefisien elastisitas sebesar 2.89 poin dan 4.77 poin dengan tanda $E>1$ (sifat: elastis) hal ini memberikan pengertian bahwa 2 tahun tersebut menunjukkan kepekaan yang cukup signifikan terhadap perubahan Pendapatan Asli Daerah (PAD).

Melalui informasi beragamnya penilaian elastisitas terhadap realisasi penerimaan retribusi parkir tepi jalan umum di Kota Jayapura, dan merujuk kepada hasil analisis growth yang berfluktuatif sepanjang tahun 2005-2015, sehingga kemampuan share terhadap Pendapatan Asli Daerah di Kota Jayapura terlihat sangat kecil dimana prosentase kontribusi terhadap kapasitas fiskal hanya berkisar 1-2 persen (sangat kurang). Melalui hasil-hasil temuan studi kuantitatif diatas, memberikan arah pandangan peneliti bahwa kurangnya konsistensi dari pemerintah daerah Kota Jayapura terkait optimalisasi potensi daerah di Kota Jayapura. Dengan

\section{Potensi Dan Tingkat Kebocoran Dalam Penerimaan Retribusi Parkir Di Tepi Jalan Umum Kota Jayapura}

Sesuai dengan konsep kebocoran yang diteliti dalam studi ini, bahwa kebocoran retribusi parkir tepi jalan umum di Kota Jayapura yang disebabkan oleh juru parkir. Dimana, berdasarkan fenomena yang terungkap bahwa, terdapat perilaku juru parkir yang tidak memberikan karcis parkir kepada pengguna jasa parkir, ataupun maraknya lahan parkir yang didominasi oleh juru parkir liar yang tidak terdaftar secara legal pada instansi teknis terkait pengelolaan pendapatan daerah Kota Jayapura.

\section{Tabel Potensi Penerimaan Retribusi Parkir Tepi Jalan Umum, menurut distrik di Kota Jayapura Tahun 2015}

\begin{tabular}{|l|c|c|c|c|c|c|}
\hline \multicolumn{1}{|c|}{ Distrik } & $\begin{array}{c}\text { Harga } \\
\text { Karcis } \\
\text { Bermotor } \\
\text { (Rp) }\end{array}$ & $\begin{array}{c}\text { Harga } \\
\text { Karcis } \\
\text { Mini } \\
\text { Bus/Sedan } \\
\text { (Rp) }\end{array}$ & $\begin{array}{c}\text { Jenis } \\
\text { Kendaraan } \\
\text { Bermotor } \\
\text { (unit) }\end{array}$ & $\begin{array}{c}\text { Jenis } \\
\text { Kendaraan } \\
\text { Mini } \\
\text { Bus/Sedan } \\
\text { (unit) }\end{array}$ & $\begin{array}{c}\text { Nilai } \\
\text { Potensi } \\
\text { Per Hari } \\
\text { (Rp/hari) }\end{array}$ & $\begin{array}{c}\text { Jumlah } \\
\text { Nilai } \\
\text { Potensi } \\
\text { Pertahun } \\
\text { (Rp/tahun) }\end{array}$ \\
\hline Abepura & 1,000 & 2,000 & 601,000 & 266,000 & 867,000 & $291,312,000$ \\
\hline Heram & 1,000 & 2,000 & 150,000 & 42,000 & 192,000 & $64,512,000$ \\
\hline Jayapura Selatan & 1,000 & 2,000 & 369,000 & 136,000 & 505,000 & $169,680,000$ \\
\hline Jayapura Utara & 1,000 & 2,000 & 693,000 & 466,000 & $1,159,000$ & $389,424,000$ \\
\hline Kota Jayapura & $\mathbf{4 , 0 0 0}$ & $\mathbf{8 , 0 0 0}$ & $\mathbf{1 , 8 1 3 , 0 0 0}$ & $\mathbf{9 1 0 , 0 0 0}$ & $\mathbf{2 , 7 2 3 , 0 0 0}$ & $\mathbf{9 1 4 , 9 2 8 , 0 0 0}$ \\
\hline
\end{tabular}

Sumber: Data diolah, Tahun 2016

Berdasarkan perolehan besaran kapasitas parkir pada objek lahan parkir, disetiap distrik. Diketahui bahwa harga balas jasa layanan retribusi parkir tepi jalan umum di Kota Jayapura ialah untuk kendaraan Bermotor ialah Rp.1.000,- untuk kendaran bertipe Mini Bus/Sedan dengan harga Rp.2.000,- dan untuk jenis 
kendaraan Truck/Pick-up seharga Rp.3.000,- untuk setiap 1 kendaraan yang menggunakan lahan parkir. Melalui hal tersebut, maka berdasarkan hasil perhitungan maka diperoleh hasil potensi Penerimaan Retribusi Parkir Tepi Jalan Umum di Kota jayapura pada 4 distrik lokasi penelitian. Memberikan gambaran potensi jasa parkir setiap tahunnya, pada distrik Abepura sebagai salah daerah pusat jasa di Kota Jayapura sebesar Rp.291.312.000,--tahun, sedangkan untuk distrik Heram yang merupakan wilayah yang cukup berdekatan dengan distrik abepura berdasarkan hasil perhitungan bahwa terdapat potensi retirbusi parkir sebesar Rp.64,512.000,-/tahun.. Untuk 2 (dua) distrik yakni pada distrik Jayapura selatan memiliki potensi retribusi parkir tepi jalan umum sebesar Rp.169.680.000 ,/tahun dan untuk distrik Jayapura Utara yang notabene merupakan pusat Kota Jayapura mampu memberikan potensi retribusi daerah sebesar Rp.389,424,000,/tahun. Sehingga berdasarkan potensi pada masing-masing distrik yang memiliki areal parkir dan jumlah penduduk yang cukup padat, maka secara hasil penelitian menunjukkan bahwa Kota Jayapura memiliki potensi retribusi aprkir tepi jalan umum sebesar Rp.914,928,000,-/tahun.

Tabel Kasus Kebocoran Penerimaan Retribusi Parkir di Tepi Jalan Umum, menurut distrik di Kota Jayapura Tahun 2015

\begin{tabular}{|l|r|r|r|r|}
\hline \multicolumn{1}{|c|}{ Distrik } & $\begin{array}{c}\text { Tidak } \\
\text { Terima } \\
\text { Karcis }\end{array}$ & $\begin{array}{c}\text { Terima } \\
\text { Karcis }\end{array}$ & $\begin{array}{c}\text { Tidak } \\
\text { Membayar } \\
\text { Karcis }\end{array}$ & $\begin{array}{c}\text { Jumlah } \\
\text { Kebocoran }\end{array}$ \\
\hline Abepura & $218,736,000$ & $58,128,000$ & $32,928,000$ & $251,664,000$ \\
\hline Heram & $39,648,000$ & & $6,720,000$ & $46,368,000$ \\
\hline Jayapura Selatan & $52,080,000$ & $20,496,000$ & $3,696,000$ & $55,776,000$ \\
\hline Jayapura Utara & $165,984,000$ & $27,888,000$ & $21,168,000$ & $187,152,000$ \\
\hline Kota Jayapura & $\mathbf{4 7 6 , 4 4 8 , 0 0 0}$ & $\mathbf{1 0 6 , 5 1 2 , 0 0 0}$ & $\mathbf{6 4 , 5 1 2 , 0 0 0}$ & $\mathbf{5 4 0 , 9 6 0 , 0 0 0}$ \\
\hline
\end{tabular}

Sumber: Data diolah, Tahun 2016

Melalui tabulasi data pada tabel diatas, mampu memberikan informasi bahwa untuk jenis kasus perilaku juru parkir yang tidak memberikan karcis kepada pelanggan setiap tahunnya berpotensi merugikan sebesar Rp.476,448,000,-sedangkan jenis kasus kebocoran yang diakibatkan oleh Tidak Membayar Karcis yang dilakukan oleh pengguna jasa parkir tepi jalan umum sebesar Rp. 64,512,000,-Realisasi penerimaan parkir berdasarkan potongan karcis resmi (Terima Karcis) hanya sebesar Rp.106,512,000,-Berdasarkan visualisasi data ini, secara kasat mata dan secara langsung dapat memberikan opini bahwa potensi parkir di Kota Jayapura mampu memberikan kontribusi yang sangat signifikan terhadap Kapasitas Fiskal daerah, namun dengan maraknya kasus kebocoran realisasi retribusi parkir hal ini menjadi 
salah satu faktor utama mengapa nilai target pemerintah daerah setiap tahunnya belum mampu direalisasikan 100 persen, atau dengan kata lain bahwa rendahnya pengelolaan retribusi parkir di Kota Jayapura belum dilaksanakan scara efektif.

Grafik Jumlah Kebocoran Penerimaan Retribusi Parkir di Tepi Jalan Umum /tahun, menurut distrik di Kota Jayapura Tahun 2015

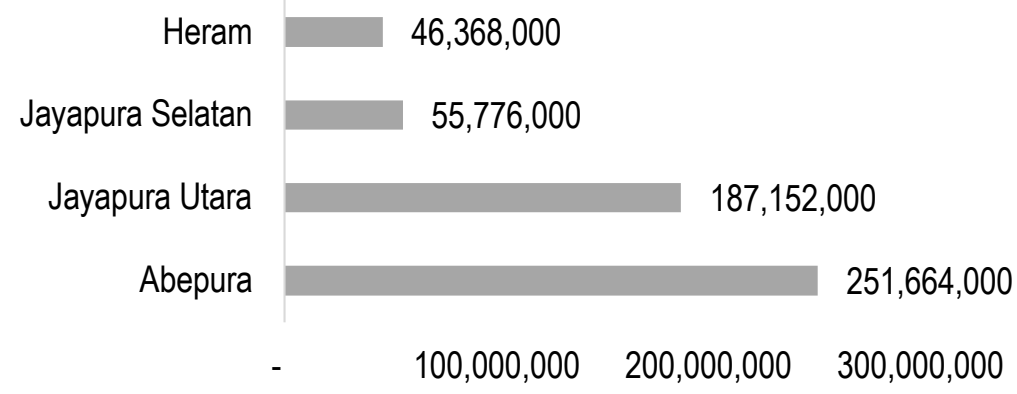

Sumber: Data diolah, Tahun 2016

Hal ini, didukung dengan kondisi dimana total kerugian retirbusi Kota Jayapura sebesar Rp. 1,610,000,- /hari, dimana wilayah abepura menjadi salah satu wilayah dengan kasus cukup tinggi mengenai kebocoran retribusi yakni sebesar Rp.651,000,- /hari, hal ini disebabkan kurangnya kontrol dari pemerintah mengenai perilaku juru parkir di distrik Abepura dan hal ini juga didukung oleh kurangnya respon masyarakat untuk dapat meminta karcis dan kurangnya perhatian masyarakat (pengguna) untuk dapat melaporkan kasuskasus seperti ini. Diikuti dengan wilayah distrik Jayapura Utara atau pusat jantung Kota Jayapura, mampu memebrikan kerugian daerah sebesar Rp.494,000,-/hari, sedangkan untuk 2 wilayah distrik masing-masing memberikan kontribusi kepada kebocoran realisasi parkir tepi jalan umum di Kota Jayapura pada distrik heram Rp.118,000,- sedangkan pada distrik Jayapura Selatan sebesar Rp.155,000,-.

Tabel Perhitungan Kebocoran Retribusi Parkir di Tepi Jalan Umum, menurut distrik di Kota Jayapura Tahun 2015

\begin{tabular}{|l|r|c|r|}
\hline \multirow{2}{*}{ Distrik } & \multicolumn{3}{|c|}{ Perhitungan Kebocoran Retribusi } \\
\cline { 2 - 4 } & $\begin{array}{c}\text { Potensi Retribusi } \\
\text { Parkir Tepi Jalan } \\
\text { Umum (Rp) }\end{array}$ & $\begin{array}{c}\text { Indikasi } \\
\text { Kebocoran } \\
\text { (Rp) }\end{array}$ & $\begin{array}{c}\text { Tingkat } \\
\text { Kebocoran }\end{array}$ \\
\cline { 4 - 5 } & $291,312,000$ & $251,664,000$ & \multicolumn{1}{c|}{$\%$} \\
\hline Abepura & $64,512,000$ & $46,368,000$ & $5.07 \%$ \\
\hline Heram & $169,680,000$ & $55,776,000$ & $6.10 \%$ \\
\hline Jayapura Selatan & $389,424,000$ & $187,152,000$ & $20.46 \%$ \\
\hline Jayapura Utara & & &
\end{tabular}




\begin{tabular}{|l|r|r|r|}
\hline Kota Jayapura & $914,928,000$ & $540,960,000$ & $59.13 \%$ \\
\hline
\end{tabular}

Sumber: Data diolah, Tahun 2016

Dengan melihat kondisi data dan informasi pada tabel diatas, memberikan pemahaman bahwa kebijakan optimalisasi perlu segera di kerahkan oleh Pemerintah Daerah Kota Jayapura, kebocoran yang terjadi dapat diindikasikan sebagai suatu tindak kerugian negara yang dilakukan oleh beberapa pihak yang terlibat langsung pada lapisan bawah sebagai juru parkir, ataupun para lapisan atas seperti para pengambil kebijakan, masyarakat pun mengambil peran besar terkait kebocoran realisasi penerimaan retribusi parkir di Kota Jayapura

Melalui tingkat kebocoran retribusi parkir tepi jalan umum di Kota Jayapura pada tahun 2015, berdasarkan informasi yang diperhatikan melalui beberapa media (Radio, Televisi) bahwa kondisi ini telah berakar bukan hanya terjadi pada tahun 2015 namun telah berlangsung cukup lama. Sehingga diindikasikan adanya pembiaraan terhadap kondisi ini. Dipahami bahwa, Kota Jayapura sebagai salah satu barometer pembangunan di Provinsi Papua sepatutnya menjadi sebuah pusat pembelajaran terkait seluruh aspek pembangunan salah satunya ialah upaya-upaya, kebijakan, stratagi, program/kegiatan terkait perwujudan semangat Otonomi Daerah dimana sangat dituntut mengenai kemandirian keuangan daerah suatu Pemerintah Daerah, dalam rangka menjalankan fungsi rumah tangga daerah.

\section{Strategi Optimalisasi Dan Mengatasi Kebocoran Retribusi Parkir Di Tepi Jalan Umum Kota Jayapura}

Dalam menangani suatu persoalan pembangunan daerah, salah satu proses yang perlu dilakukan ialah menyusun suatu strategi kebijakan. Persoalan retirbusi parkir merupakan salah satu isu kapasitas fiskal yang belum optimal dikelola oleh Pemerintah Daerah Kota Jayapura.

Berdasarkan hasil temuan lapangan, identifikasi yang dilakukan terhadap juru parkir yang resmi, maka beberapa hal penting dapat terpotret mengenai situasi akar rumput pelayanan retribusi parkir di Kota Jayapura mengenai beberapa Aspek antara lain: (1) Aspek Regulasi Daerah, (2) Aspek Pelaksanaan Pemungutan Retribusi; (3) Aspek Pengawasan/Pembinaan Pemungut Retribusi; (4) Aspek Pelaporan Pemungut Retribusi;

Melalui informasi yang diperoleh dari angket yang diberikan kepada juru parkir, maka secara umum berdasarkan parameter dalam angket maka menunjukkan bahwa berdasarkan respon juru parkir setoran penerimaan 
retribusi parkir dilakukan setiap harinya kepada petugas pengumpul, namun terdapat beberapa petugas yang masih mengeluh mengenai pendapatan bulanan yang diperoleh yang masih sangat kecil. Pada tahun 2014, pemerintah Kota Jayapura telah melakukan suatu studi mengenai evaluasi Pendapatan Asli Daerah, yang dilakukan oleh Pemerintah Daerah Kota Jayapura, terdapat beberapa hal pokok yang menjadi persoalan. Yang mana perlu tindak lajut yang bersifat penting untuk dikerjakan antara lain:

1. Regulasi;

2. Sumber Daya Manusia;

3. Kesadaran Masyarakat;

4. Kelembagaan;

5. Sistem dan Prosedur;

Aspek-aspek yang menjadi temuan dalam hasil evaluasi Pendapatan Asli Daerah $(P A D)$ di Kota Jayapura diatas, secara umum merupakan poin-poin yang menjadi temuan dalam penelitian ini. Berdasarkan hasil evaluasi yang dilakukan ini, dapat diasumsikan bahwa 5 aspek ini memiliki pengaruh yang berarti terhadap kasus-kasus yang terjadi berdasarkan hasil penelitian diatas. Oleh sebab itu, perlu dilakukan analisis mendalam dalam rangka penyusunan model atau strategi-strategi dalam penanganan persoalan retribusi parkir tepi jalan umum di Kota Jayapura.

Adapun rumusan strategi dalam optimalisasi Penerimaan Asli Daerah Kota Jayapura melalui optimalisasi Retribusi Parkir Tepi Jalan umum, dan pengurangan tingkat kebocoran penerimaan retirbusi parkir sebagai berikut:

Tabel Perumusan Strategi Optimalisasi

Retribusi Parkir Tepi Jalan Umum Dan Pengurangan Tingkat Kebocoran Penerimaan Retribusi Parkir di Kota Jayapura

\begin{tabular}{|c|c|c|c|}
\hline No & Aspek & $\begin{array}{c}\text { Kendala dan } \\
\text { Tantangan }\end{array}$ & $\begin{array}{l}\text { Strategi } \\
\text { Kebijakan }\end{array}$ \\
\hline \multirow[t]{3}{*}{1.} & \multirow[t]{3}{*}{$\begin{array}{l}\text { Aspek } \\
\text { Regulasi }\end{array}$} & $\begin{array}{lr}\text { a. } & \text { Belum } \\
\text { regulasi } & \text { optimalnya } \\
\text { mengenai } & \text { daerah } \\
\text { Daetribusi }\end{array}$ & $\begin{array}{l}\text { Meningkatkan fungsi } \\
\text { pengawasan dan monitoring dan } \\
\text { evaluasi }\end{array}$ \\
\hline & & $\begin{array}{l}\text { b. Juru parkir belum } \\
\text { memahami secara baik } \\
\text { tentang regulasi daerah; }\end{array}$ & $\begin{array}{l}\text { Peningkatan kapasitas dan } \\
\text { pemahaman juru parkir terhadap } \\
\text { aturan mengenai retirbusi }\end{array}$ \\
\hline & & $\begin{array}{l}\text { c. Belum maksimalnya } \\
\text { sosialisasi mengenai } \\
\text { aturan yang berkaitan } \\
\text { dengan retribusi parkir } \\
\text { tepi jalan umum; }\end{array}$ & $\begin{array}{ll}\text { Mendorong adanya } & \text { publikasi } \\
\text { dan transparansi } & \text { informasi } \\
\text { mengenai tatakelola } & \text { retribusi } \\
\text { parkir tepi jalan umum } & \end{array}$ \\
\hline 2. & Aspek & a. Maraknya juru parkir & Menata \\
\hline
\end{tabular}


Jurnal Keuda Vol. 2 No. 1

ISSN 2477-7838

\begin{tabular}{|c|c|c|c|}
\hline No & Aspek & $\begin{array}{c}\text { Kendala dan } \\
\text { Tantangan }\end{array}$ & $\begin{array}{l}\text { Strategi } \\
\text { Kebijakan }\end{array}$ \\
\hline & \multirow[t]{5}{*}{$\begin{array}{l}\text { Pelaksanaan } \\
\text { Pemungutan } \\
\text { Retribusi }\end{array}$} & liar; & $\begin{array}{l}\text { Menertibkan juru parkir dengan } \\
\text { melibatkan beberapa instansi } \\
\text { terkait; }\end{array}$ \\
\hline & & $\begin{array}{lr}\text { b. Tingkat } & \text { kesadaran } \\
\text { masyarakat r yang } \\
\text { rendah untuk membayar } \\
\text { tariff parkir; }\end{array}$ & $\begin{array}{l}\text { Melakukan sosialisasi \& } \\
\text { advokasi mengenai peranan } \\
\text { retribusi dalam pembangunan } \\
\text { berkelanjutan }\end{array}$ \\
\hline & & $\begin{array}{l}\text { c. Perilaku juru parkir yang } \\
\text { kurang professional; }\end{array}$ & $\begin{array}{l}\text { Menerapkan pemberian sanksi } \\
\text { administrasi kepada juru parkir }\end{array}$ \\
\hline & & $\begin{array}{l}\text { d. Area parkir yang tidak } \\
\text { ditata dengan baik; }\end{array}$ & $\begin{array}{l}\text { Penataan area parkir sesuai } \\
\text { dengan kondisi wilayah dan } \\
\text { kapasitas kendaraan }\end{array}$ \\
\hline & & $\begin{array}{l}\text { e. Keamanan parkir yang } \\
\text { masih rendah; }\end{array}$ & $\begin{array}{l}\text { Memperketat pengawasan } \\
\text { melalui juru parkir dan adanya } \\
\text { papan peringatan pada setiap } \\
\text { area parkir }\end{array}$ \\
\hline \multirow[t]{3}{*}{3.} & \multirow{2}{*}{$\begin{array}{l}\text { Aspek } \\
\text { Pengawasan/ } \\
\text { Pembinaan } \\
\text { pemungutan } \\
\text { retribusi }\end{array}$} & $\begin{array}{l}\text { a. Tindak Lanjut hasil } \\
\text { pengawasan/MONEV } \\
\text { yang masih rendah; }\end{array}$ & $\begin{array}{l}\text { Penyediaan JUKLAK/JUKNIS } \\
\text { mengenai fungsi pengawasan } \\
\text { dan MONEV }\end{array}$ \\
\hline & & $\begin{array}{l}\text { b. Kurangnya pembinaan } \\
\text { secara regular; }\end{array}$ & $\begin{array}{lr}\text { Pengendalian kebocoran } \\
\text { retribusi parkir melalui kegiatan } \\
\text { pembinaan yang dilakukan } \\
\text { secara periodik }\end{array}$ \\
\hline & & $\begin{array}{l}\text { c. Kurangnya peran distrik } \\
\text { dalam hal pengawasan }\end{array}$ & $\begin{array}{l}\text { Menjalin kerjasama dengan } \\
\text { pihak distrik untuk melakukan } \\
\text { fungsi pengawasan terpadu }\end{array}$ \\
\hline 4. & $\begin{array}{l}\text { Aspek } \\
\text { Pelaporan } \\
\text { Pemungut } \\
\text { Retribusi }\end{array}$ & $\begin{array}{l}\text { a. Akuntabilitas } \\
\text { Transparansi } \\
\text { pengelolaan } \\
\text { daerah; }\end{array}$ & $\begin{array}{l}\text { Penyediaan } \\
\text { mekanisme pelaporan dan } \\
\text { pembagian keuntungan yang } \\
\text { profesional }\end{array}$ \\
\hline
\end{tabular}

Sumber: Data diolah, 2016

\section{KESIMPULAN DAN SARAN}

\section{Kesimpulan}

a. Pengelolaan retribusi parkir tepi jalan umum di Kota Jayapura, belum dilaksanakan secara efektif dalam rangka optimalisasi potensi Penerimaan Asli Daerah. Hal ini antara lain dapat ditemukan adanya kebocoran sekitar $59 \%$ pertahun.

b. Dalam mengantisipasi persoalan kebocoran realisasi dan optimalisasi potensi Parkir Tepi Jalan Umum di Kota Jayapura, hal ini dapat dilakukan melalui strategi peningkatan maupun penataan Aspek Regulasi, Sumber Daya Manusia, Kesadaran Masyarakat, Kelembagaan, dan Sistem dan Prosedur. 


\section{Saran}

a. Dalam rangka menunjang peningkatan Pendapatan Asli Daerah (PAD), sebaiknya Pemerintah Kota Jayapura perlu meningkatkan kebijakan optimalisasi dan pengelolaan yang retribusi parkir tepi jalan umum yang lebih efektif.

b. Untuk meminimalisir setiap kebocoran realisasi parkir setiap tahunnya, maka Pemerintah Kota Jayapura perlu melakukan pemantauan dan pengawasan yang maksimal dalam hal pengelolaan potensi yang ada, salah satu langkah yang dapat diterapkan ialah melibatkan pihak swasta (pihak ketiga) untuk dapat menjalankan fungsi pengawasan atau memberdayakan setiap pertokoan yang merupakan area parkir untuk dapat menyediakan satu orang petugas parkir yang dapat dikontrol langsung oleh manajemen toko.

c. Pemerintah Daerah perlu segera membangun strategi peningkatan maupun penataan aspek Regulasi, Sumber Daya Manusia, Kesadaran Masyarakat, Kelembagaan, dan Sistem dan Prosedur pengelolaan Retribusi Parkir Tepi Jalan Umum di Kota Jayapura.

\section{DAFTAR PUSTAKA}

Adhi.2012, Analisis Pengaruh Retribusi Parkir Kendaraan Terhadap Pendapatan Asli Daerah (PAD). Kota Surakarta.

Baridwan, Z. 1998. Sistem Akuntansi: Penyusunan Prosedur dan Metode. BPFE. Yogyakakarta.

Badan Pusat Statistik. 2004. Data Dalam Angka Kota Jayapura. BPS, Kota Jayapura.

Badan Pusat Statistik. 2010. Data Dalam Angka Kota Jayapura. BPS, Kota Jayapura.

Badan Pusat Statistik. 2015. Data Dalam Angka Kota Jayapura. BPS, Kota Jayapura.

Efendi. 2014. Mencari Solusi Manajemen Dalam Pemenuhan Target Penerimaan Pajak Dan Retribusi Parkir. Kota Medan

Halim, A. 2004. Manajemen Keuangan Daerah. UPP-AMP YKPN, Yogyakarta

Kususma. 2012. Pengawasan Peyelenggaraan Retribusi Parkir Oleh Dinas Perhubungan , Komunikasi, dan Informatika. Kota Serang

Munawir, S. 1990. Perpajakan. BPFE. Jogjakarta.

Mamesah, DJ. 1995. Sistem administrasi keuangan daerah. Gramedia Pustaka Utama. Jakarta.

Pasolo, 2013.. DISPENDA Akan Tambah Juru Parkir Resmi www.bintangpapua.com, diakses pada, Senin 8 Juli 2013))

Pasolo, 2013.. Potensi Parkir di Kota Jayapura Baru 20 Persen Tergarap bintangpapua.com, diakses pada, Rabu 12 Desember 2014) 
Jurnal Keuda Vol. 2 No. 1

ISSN 2477-7838

Pasolo, 2014. Pemkot Jayapura Kesulitan Atasi Juru Parkir Liar. www.tabloidjubi.com, diakses pada, Rabu 21 Mei 2014)

Pasolo, 2014. Parkir Berlangganan Akan Diterapkan Di Kota Jayapura. www.beritasatu.com, diakses pada Kamis, 4 September 2014)

Prawirohardjo, Saswono. 2006. Metode Penelitian Kuantitatif dan Kualitatif. Graha IImu. Jogjakarta

Peraturan Daerah Nomor 14. 2007. Tentang Pelayanan Retribusi Parkir Tepi Jalan Umum. Kota Jayapura

Undang-Undang Nomor 17. 2003. Tentang Pengelolaan Keuangan Daerah

Undang-Undang Nomor 32. 2004. Tentang Pemerintahan Daerah

Undang-Undang Nomor 33. 2004. Tentang Penimbangan Keuangan antara Pemerintah Pusat dan Pemerintah Daerah

Undang-undang Nomor 28. 2009. Tentang Pajak Daerah dan Retribusi Daerah

www.dispedapapua.com. Dinas Pendapatan Daerah Provinsi Papua

www.djpk.com. Direktorat Jenderal Perimbangan Keuangan.

www.papua.go.id. Pemerintah Provinsi Papua

Yuwono, Sony; Dwi Cahyo Utomo; H. Suheiry Zein; H. Azrafiany A.R. 2008. Memahami APBD dan Permasalahannya: Panduan Pengelolaan Keuangan Daerah. Banyumedia Publishing. Malang

Zufrizen. 2013, Analisis Potensi Penerimanaan Retribusi Parkir Pada Pusat-Pusat Perbelanjaan. Kota Medan. 